Abstracta Iranica Iranica

Revue bibliographique pour le domaine irano-aryen

Volume 22 | 2001

Comptes rendus des publications de 1999

\title{
La mystique de Gibran et le supra-confessionalisme religieux des chrétiens d'Orient. Paris, Les Deux Océans, 1998, 199 p.
}

\section{Pierre Lory}

\section{(2) OpenEdition}

1 Journals

\section{Édition électronique}

URL : http://journals.openedition.org/abstractairanica/36746

DOI : 10.4000/abstractairanica.36746

ISSN : 1961-960X

Éditeur :

CNRS (UMR 7528 Mondes iraniens et indiens), Éditions de l'IFRI

\section{Édition imprimée}

Date de publication : 15 mai 2001

ISSN : 0240-8910

Référence électronique

Pierre Lory, « La mystique de Gibran et le supra-confessionalisme religieux des chrétiens d'Orient. Paris, Les Deux Océans, 1998, 199 p. », Abstracta Iranica [En ligne], Volume 22 | 2001, document 330, mis en ligne le 17 février 2010, consulté le 13 octobre 2020. URL : http://journals.openedition.org/ abstractairanica/36746 ; DOI : https://doi.org/10.4000/abstractairanica.36746

Ce document a été généré automatiquement le 13 octobre 2020

Tous droits réservés 


\section{La mystique de Gibran et le supra- confessionalisme religieux des chrétiens d'Orient. Paris, Les Deux Océans, 1998, 199 p.}

Pierre Lory

Cet essai se propose d'analyser la démarche de plusieurs auteurs libanais ayant cherché à surmonter le cloisonnement confessionnel tellement ancré dans leur patrie : Gibran avant tout, mais aussi Rihani et d'autres essayistes moins connus. Il est intéressant de noter la référence récurrente à la pensée iranienne. J. Hatem insiste sur le rôle de la dimension imaginale dans la spiritualité gibranienne, et signale la présence de personnages renvoyant au chiisme (Zayn al-'Ābidīn ; Āmina al-'Alawiyya, p. 42) dans ses textes. Il note d'autre part l'impact du bahaïsme, vécu par plusieurs des intellectuels concernés (Ibrahim Khayrallah, Rihani) comme une voie de sortie résolvant les blocages religieux actuels.

\section{INDEX}

Thèmes : 7. Islam 
AUTEURS

PIERRE LORY

EPHE - Paris 